\title{
IMPACT OF ETHANOL, METHANOL AND SULFIDES ON THE NITRIFICATION PROCESS OF AMMONIUM IONS IN NATURAL WATERS
}

\author{
Maria Sandu' ${ }^{1}$, Anatol Tărîță ${ }^{1}$, Tudor Lupaşcu², Galina Dragalina ${ }^{3}$, \\ Elena Moșanu ${ }^{1}$ \\ ${ }^{1}$ Institute of Ecology and Geography, Chişinău, Republic of Moldova \\ ${ }^{2}$ Institute of Chemistry, Chişinău, Republic of Moldova \\ ${ }^{3}$ Faculty of Chemistry and Chemical Technology, State University of Moldova, Chişinău, \\ Republic of Moldova \\ *Corresponding authors: sandu_mr@yahoo.com, anatolietarita@gmail.com
}

Keywords: ammonium, nitrites, nitrates, nitrification, ethanol, methanol, sulfides.

\begin{abstract}
This paper includes the results of laboratory modeling of ethyl and methyl alcohol and sulfide ions impact on the biochemical process of ammonium ions nitrification in water from the Dniester River, Palanca village, Stefan Voda district (august 2019). An insignificant influence of ethyl and methyl alcohol (0,5 ml/L) was established in both stages of the process. In the comparison test, the stage $\mathrm{NH}_{4}{ }^{+} \rightarrow$ $\mathrm{NO}_{2}^{-}$lasted 12 days, and in the presence of ethyl alcohol - 14 days and in the presence of methyl alcohol - 16 days. The $\mathrm{NO}_{2}{ }^{-} \rightarrow \mathrm{NO}_{3}{ }^{-}$stage in the comparison test lasted 16 days and in the presence of ethyl alcohol 2 days less (14 days) and in the presence of methyl alcohol - 16 days, so without any influence. The study showed a significant influence of sulfur ion in both stages at a concentration of $0.1 \mathrm{mg} / \mathrm{L}$ with and without the presence of ethyl and methyl alcohol. In the comparison test, the $\mathrm{NH}_{4}{ }^{+} \rightarrow \mathrm{NO}_{2}^{-}$stage lasted 12 days, in the presence of the $\mathrm{S}^{2-}$ ion it lasted 18 days, and in the presence of alcohols and sulfur ion - more than 20 days, the synergism of the impact being obvious. In the $\mathrm{NO}_{2}{ }^{-} \rightarrow \mathrm{NO}_{3}{ }^{-}$step of the process for 20 days the $\mathrm{NO}_{2}^{-}$concentration did not decrease in the presence of the $\mathrm{S}^{2-}$ ion, and in the presence of ethyl, methyl alcohol and $\mathrm{S}^{2-}$ only $15-35 \%$ of the $\mathrm{NO}_{2}^{-}$ions were oxidized, in comparison with the witness test.
\end{abstract}

\section{INTRODUCTION}

Inorganic nitrogen compounds $\left(\mathrm{NH}_{4}^{+}, \mathrm{NH}_{3}, \mathrm{NO}_{2}^{-}, \mathrm{NO}_{3}^{-}\right)$are present practically in all natural waters, the content of which is conditioned by their amount in existing sources of pollution: wastewater discharged into the environment, the presence of industrial, agricultural, household waste illegally 
stored, atmospheric deposits and surface runoff and as a result of their biochemical transformation [3].

As a result of the discharge of wastewater from Chisinau municipality into the water of Bâc river were detected $119 \mathrm{mg} / \mathrm{L} \mathrm{NH}_{4}{ }^{+}$, and in Cogâlnic district, downstream of Hânceşti city - $24.2 \mathrm{mg} / \mathrm{L} \mathrm{NH}_{4}{ }^{+}$[12]. By evaluating the physicalchemical composition of the Bâc river water at the discharge into the Dniester river was found the presence of $32,6-33,8 \mathrm{mg} / \mathrm{L}$ of ammonium ions [28].

Ammonium, nitrites and nitrates ions have different toxicity for hydrobionts, and surface waters are classified into 5 quality classes according to their concentration: for nitrates from 1,0 to $>11,3 \mathrm{mg} \mathrm{N} / \mathrm{L}$; nitrites from 0,01 to $>0,3 \mathrm{mg}$ $\mathrm{N} / \mathrm{L}$ and for ammonium from 0,2 to $>3,1 \mathrm{mg} \mathrm{N} / \mathrm{L}$ [8]. Their presence in water determines the excessive growth of algae causing eutrophication of the aquatic basin [5], and by deteriorating the ecological balance of the aquatic ecosystem; the water quality is also diminished.

Sulfides $\left(\mathrm{S}^{2-}, \mathrm{H}_{2} \mathrm{~S}\right)$ are present in wastewater from various economic fields, including domestic, and cause an unpleasant odor already at a concentration of 0,05 $\mathrm{mg} / \mathrm{L}$ in drinking water [7], but are missing in the list of pollutants to be monitored by the regulation on environmental quality requirements for surface waters [8].

Methyl and ethyl alcohols are also not specified in Government Decision no. 890 of 12.11.2013 [8] and in the Regulation on wastewater collection, treatment and discharge requirements [10], but scientific research has been conducted on their impact on the denitrification process, an example from recent studies of domestic wastewater [2,14] and drinking water [16], being an argument for the purpose of this study of the perpetuation of nitrogen in natural water and, in particular, the oxidation of $\mathrm{NH}_{4}{ }^{+}$ion in the presence of various pollutants present in water: ethanol, methanol and sulfides.

In natural waters ammonium transformations take place through the nitrification process - biological oxidation in two stages: a) with the formation of nitrite ions and $b$ ) with the formation of nitrate ions, respectively by Nitrosomonas and Nitrobacter.

$$
\begin{aligned}
& \text { a) } 2 \mathrm{NH}_{4}^{+}+3 \mathrm{O}_{2}=2 \mathrm{NO}_{2}^{-}+4 \mathrm{H}^{+}+2 \mathrm{H}_{2} \mathrm{O} \\
& \text { b) } 2 \mathrm{NO}_{2}^{-}+\mathrm{O}_{2}=2 \mathrm{NO}_{3}^{-}
\end{aligned}
$$

The transformation reactions are coupled and take place rapidly until the formation of nitrates, which can be applied to plant growth or the need to remove them from their waters can be reduced by denitrification. 
Microbiological processes (nitrification and denitrification) are influenced by temperature, $\mathrm{pH}$, redox potential, the presence of inhibitors and the amount of oxygen in the water.

Nitrification is characterized by high oxygen consumption (for oxidation 1 $\mathrm{mg} / \mathrm{L}$ of $\mathrm{NH}_{4}{ }^{+}$consumes about $3,6 \mathrm{mg} / \mathrm{L} \mathrm{O}$ ), and an insufficient supply of oxygen can lead to the accumulation in water only of nitrites, which leads to creating exceptional situations [6].

Frequent pollution of natural waters with chemicals inhibits the biochemical processes in the environment. Previously has been studied the influence of phenol, petroleum products, heavy metals and pesticides, surfactants, etc., on the process of ammonium nitrification in surface waters $[17,18,25,26]$, because these substances are used in domestic activity in various fields of the economy.

The following paper includes the results obtained by laboratory modeling of the impact of ethyl and methyl alcohols and sulfides in the biochemical process of ammonium ions nitrification in natural water.

\section{MATERIALS AND METHODS}

The influence of ethyl and methyl alcohols and sulfides on the process of biochemical oxidation of ammonium ions was assessed by determining for 20 days the concentration of $\mathrm{NH}_{4}{ }^{+}, \mathrm{NO}_{2}{ }^{-}$ions and $\mathrm{pH}$, using national standards [22-24], and $\mathrm{NO}_{3}{ }^{-}$ion by the method in the presence of $\mathrm{NO}_{2}{ }^{-}[19]$.

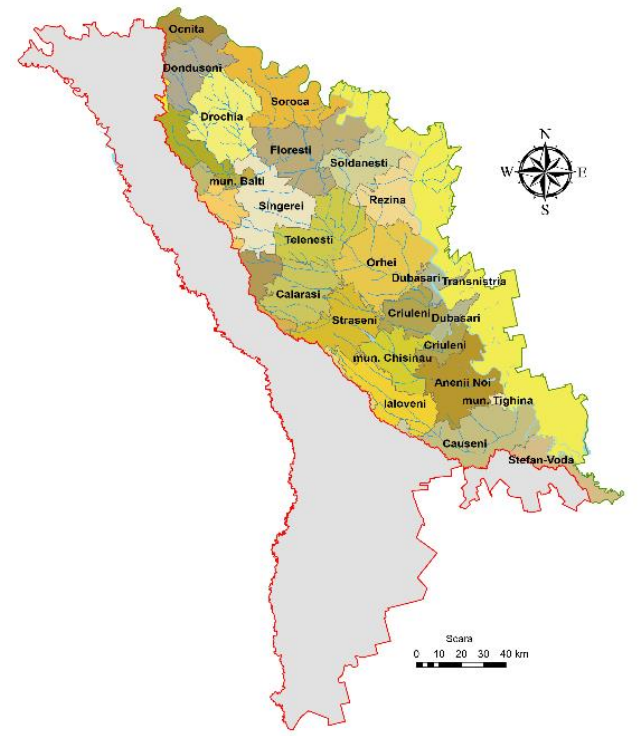

Figure 1. The map (scheme) of the hydrological basin of Dniester River (Republic of Moldova). 
The study of the process was performed using laboratory modeling in glass vessels exposed to sunlight (direct sunlight was excluded). Water was used for the experiment from the Dniester River, Palanca village, Stefan Voda district, Republic of Moldova (fig. 1).

The initial concentration of ammonium ions in water was $0,11 \mathrm{mg} / \mathrm{L}$ and was increased to $2,36 \mathrm{mg} / \mathrm{L}$ (permissible in urban and industrial wastewater at discharges - $2 \mathrm{mg} / \mathrm{L} \mathrm{[10])} \mathrm{with} \mathrm{ammonium} \mathrm{sulfate} \mathrm{solution.} \mathrm{The} \mathrm{comparison} \mathrm{sample}$ includes natural water with an $\mathrm{NH}_{4}{ }^{+}$content of $2,36 \mathrm{mg} / \mathrm{L}$. The concentration of ethyl and methyl alcohol was $0,5 \mathrm{ml} / \mathrm{L}$ of water, taken at random, because it is not regulated in environmental normative documents. The concentration of sulfides $\left(\mathrm{S}^{2-}\right)$ in the experiment was taken $0,1 \mathrm{mg} / \mathrm{L}, 5$ times lower than the limited allowable in urban and industrial wastewater at discharges in emission $(0,5 \mathrm{mg} / \mathrm{L})$ [10].

Were used chemicals of "pure for analysis" or "chemically pure" quality. The modeling was performed at a temperature of $20-22^{\circ} \mathrm{C}$.

\section{RESULTS AND DISCUSSIONS}

The study of the process of nitrification of ammonium ions is important for river ecosystems and biota present in waters specific to the nitrogen cycle. Nitrification evaluation is also characteristic during aerobic/anaerobic decomposition reactions in wastewater treatment technologies, when nitrogen from organic substances is transformed into inorganic nitrogen compounds toxic to aquatic biota. An example is the information in Council Directive 78/659 / EEC of 18.07.1978 on the permissible concentration of ammonium ions, ammonia and nitrites in water for the maintenance of fish life: salmon waters: $\leq 0,005 \mathrm{mg} / \mathrm{L}$ $\mathrm{NH}_{3} ; \leq 0,04 \mathrm{mg} / \mathrm{L} \mathrm{NH}_{4}{ }^{+} ; \leq 0,01 \mathrm{mg} / \mathrm{L} \mathrm{NO}_{2} ;$; cyprinoid waters: $\leq 0,005 \mathrm{mg} / \mathrm{L}$ $\mathrm{NH}_{3} ; \leq 0,2 \mathrm{mg} / \mathrm{L} \mathrm{NH}_{4}^{+} ; \leq 0,03 \mathrm{mg} / \mathrm{L} \mathrm{NO}_{2}{ }^{-}[4]$ and limited allowance of $0,5 \mathrm{mg} / \mathrm{L}$ $\mathrm{NH}_{4}{ }^{+}$and $\mathrm{NO}_{2}^{-}$for drinking water [9].

The influence of ethyl alcohol, methyl alcohol and sulfides on $\mathrm{NH}^{+}$ion nitrification.

In some studies, some correlations have been proposed that characterize the denitrification process with the use of ethyl and methyl alcohol [13].

$$
\begin{gathered}
5 \mathrm{CH}_{3} \mathrm{OH}+6 \mathrm{NO}_{3}^{-}=5 \mathrm{CO}_{2}+7 \mathrm{H}_{2} \mathrm{O}+6 \mathrm{OH}^{-} \\
5 \mathrm{C}_{2} \mathrm{H}_{5} \mathrm{OH}+10 \mathrm{NO}_{3}^{-}=5 \mathrm{~N}_{2}+10 \mathrm{CO}_{2}+15 \mathrm{H}_{2} \mathrm{O}
\end{gathered}
$$

Denitrification research into reactors that simulate effluents from domestic wastewater treatment plants using methanol, ethanol and methane as electron donors based on kinetic parameters [20] has shown that the most efficient electron 
donor was ethanol, which completely removed nitrogen and nitrates in $50 \mathrm{~min}$, the same efficiency being obtained by feeding the reactors with methanol and methane for 120 and $315 \mathrm{~min}$, respectively. The model is simple and expresses the conversion of nitrate directly to molecular nitrogen.

In some data of the relevant ministry (Ministry of Agriculture and Food Industry, currently the Ministry of Agriculture, Regional Development and Environment) it is specified that 162 licensed economic agents were active in the manufacture, storage and marketing of alcohol production in the Republic of Moldova [28]. For example, during 2016, alcohol production was manufactured in a total volume of 5706.3 thousand liters [1], being used in various fields, some with an impact on the environment, which means that their residues can reach wastewater in the basins.

Methyl alcohol is designed for use in the process of denitrification of wastewater / sludge from Biological Sewage Treatment Plant in Chisinau municipality. The most complex biological treatments include the removal of nitrogen compounds from wastewater. Nitrogen is present in raw domestic wastewater mostly in the form of ammonium $\left(\mathrm{NH}_{4}{ }^{+}\right)$, which is oxidized by autotrophic bacteria to nitrate $\left(\mathrm{NO}_{3}{ }^{-}\right)$and then reduced by specific bacteria to $\mathrm{N}_{2}$ under anoxic conditions, the process taking place in the presence of methanol as a carbon source [15]. So, the method is based on improving the activity of denitrifying bacteria, which occur naturally when a slightly degradable organic chemical is added, which the bacteria oxidize and simultaneously reduce the nitrate to nitrogen gas.

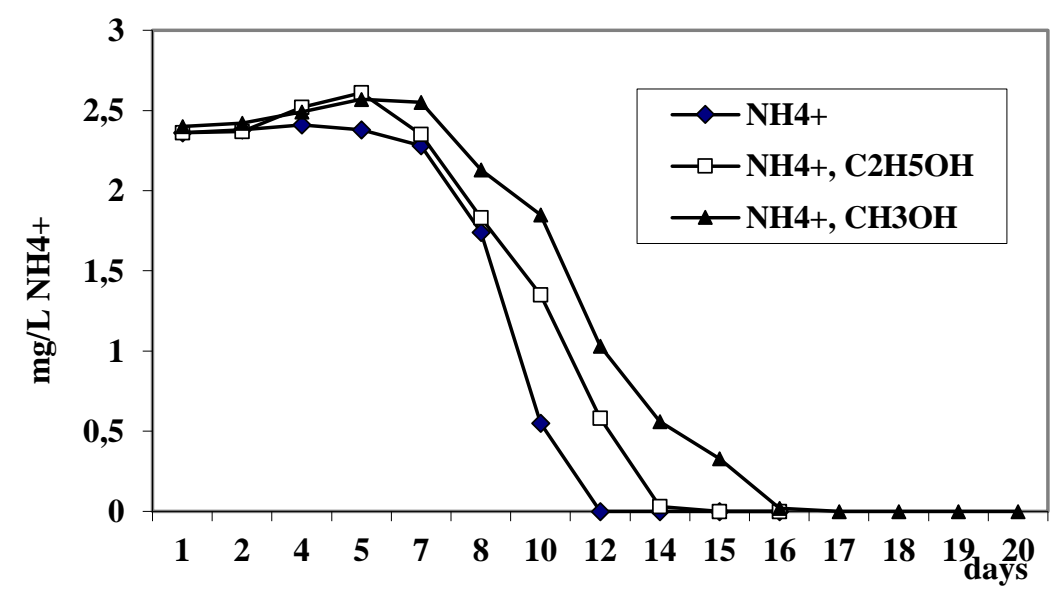

Figure 2. The step $\mathrm{NH}_{4}{ }^{+} \rightarrow \mathrm{NO}_{2}{ }^{-}$of the nitrification process in the presence of ethyl and methyl alcohol. 
As sulfides $\left(\mathrm{S}^{2-}, \mathrm{H}_{2} \mathrm{~S}\right)$ are not included in the list of substances monitored by the Regulation on environmental quality requirements for surface waters [8], but are present in wastewater discharged into the environment, it has been of scientific interest evaluating their impact on the nitrification process in natural waters.

As a result of the evaluation of the process of nitrification of ammonium ions in the water from Dniester River, Palanca village, Ştefan Vodă district (august 2019), an insignificant influence of ethyl and methyl alcohol was established (added in the experiment $0,5 \mathrm{ml} / \mathrm{L} \mathrm{C}_{2} \mathrm{H}_{5} \mathrm{OH}$ and $\mathrm{CH}_{3} \mathrm{OH}$ ) in both stages of the process. In the comparison test (control), which includes natural water with the addition of $\mathrm{NH}_{4}{ }^{+}$of $2,36 \mathrm{mg} / \mathrm{L}$, the $\mathrm{NH}_{4}{ }^{+} \rightarrow \mathrm{NO}_{2}{ }^{-}$step of the nitrification process lasted 12 days, and in the presence of ethyl alcohol by 2 days more (14 days) and in the presence of methyl alcohol - 4 days longer (16 days) (fig. 2).

The $\mathrm{NO}_{2}^{-} \rightarrow \mathrm{NO}_{3}^{-}$step of the nitrification process in the comparison test lasted 16 days, in the presence of ethyl alcohol by 2 days less (14 days) and in the presence of methyl alcohol - 16 days, so without influence (fig. 3).

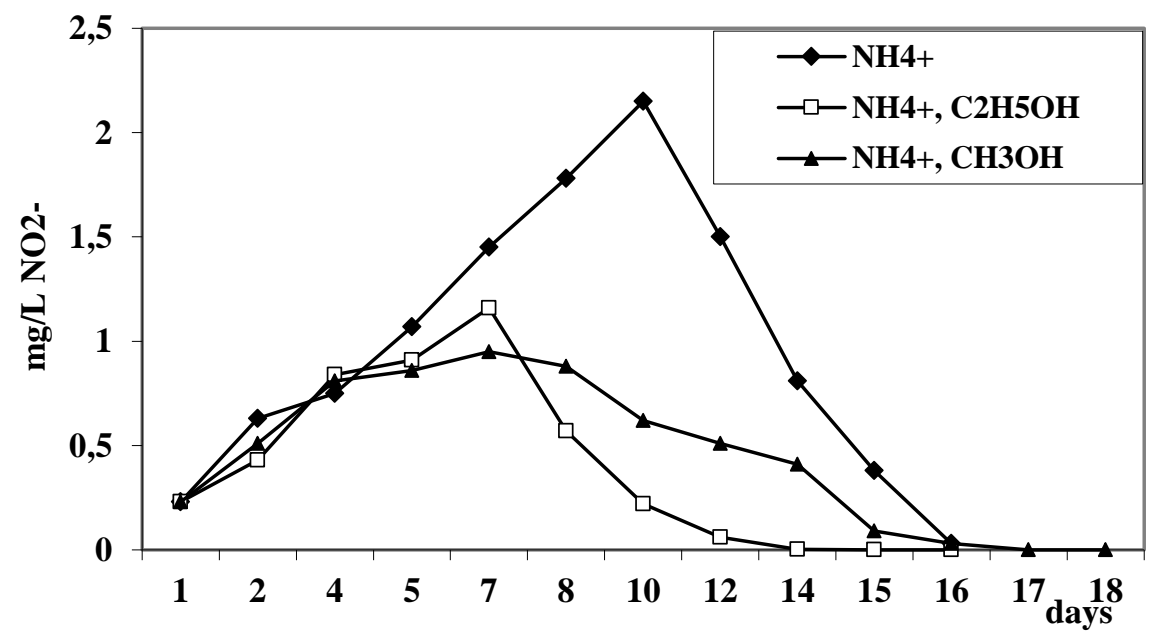

Figure 3. The step $\mathrm{NO}_{2}{ }^{-} \rightarrow \mathrm{NO}_{3}{ }^{-}$of the nitrification process in the presence of ethanol and methanol.

The study of the ammonium nitrification process shows a significant influence of the sulfide ion on both stages at the concentration of $0,1 \mathrm{mg} / \mathrm{L}$ with and without the presence of ethyl and methyl alcohol. If in the comparison test the stage $\mathrm{NH}_{4}{ }^{+}$ $\rightarrow \mathrm{NO}_{2}^{-}$lasted 12 days, in the presence of the $\mathrm{S}^{2-}$ ion it lasted 18 days, and in the presence of alcohols and sulfur ion - more than 20 days (fig. 4), being obviously the synergism of the impact. 


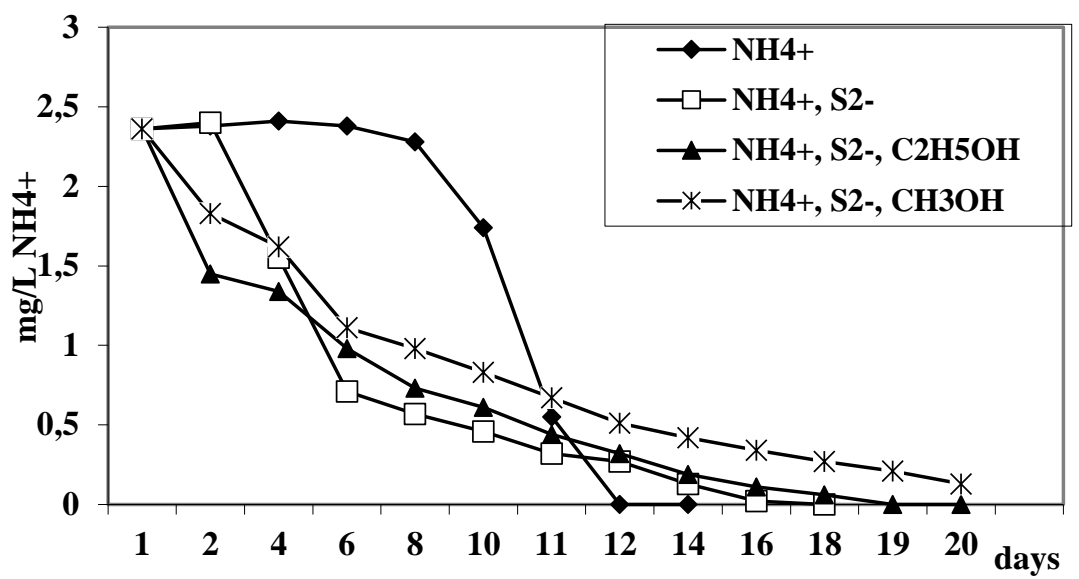

Figure 4. The step $\mathrm{NH}_{4}{ }^{+} \rightarrow \mathrm{NO}_{2}-$ from the nitrification process in the presence of sulfur ion and ethanol and methanol.

In the $\mathrm{NO}_{2}^{-} \rightarrow \mathrm{NO}_{3}^{-}$stage of the nitrification process for 20 days the $\mathrm{NO}_{2}^{-}$ concentration did not decrease in the presence of the $\mathrm{S}^{2-}$ ion and in the presence of ethyl, methyl and $\mathrm{S}^{2-}$ alcohol only $15-35 \%$ of the $\mathrm{NO}_{2}^{-}$ions were oxidized, in comparison with the control sample (fig. 5).

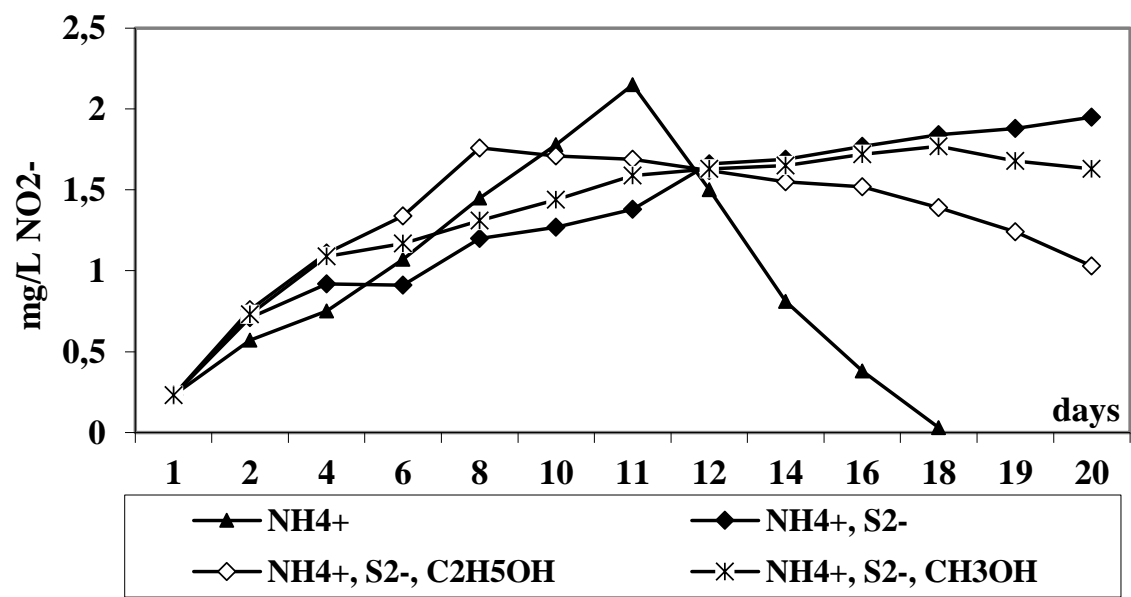

Figure 5. The step $\mathrm{NO}_{2}{ }^{-} \rightarrow \mathrm{NO}_{3}{ }^{-}$from the nitrification process in the presence of sulfur ion and ethyl and methyl alcohol. 
As a result of the modeling process, the $\mathrm{pH}$ of the water decreased from 8,03 to 7,55. The nitrate content increased from $4,6 \mathrm{mg} / \mathrm{L}$ to about $13 \mathrm{mg} / \mathrm{L}$ in the comparison sample (water from the Dniester River with a concentration of 2,36 mg / $\mathrm{L} \mathrm{NH}_{4}{ }^{+}$), in the other samples decreasing to about $2,7 \mathrm{mg} / \mathrm{L} \mathrm{NO}_{3}^{-}$in water with the addition of $0,5 \mathrm{ml} / \mathrm{L} \mathrm{C}_{2} \mathrm{H}_{5} \mathrm{OH}$ and $\mathrm{CH}_{3} \mathrm{OH}$, the argument may be the denitrification of nitrates in the presence of alcohol.

In the samples with the addition of $0,1 \mathrm{mg} / \mathrm{L} \mathrm{S}^{2-}$, including alcohols, the nitrate content did not change substantially and was $3,6-4,1 \mathrm{mg} / \mathrm{L}$, which demonstrates the impact of sulfides on both the nitrification process and denitrification, varying depending on the concentration of alcohol and other pollutants, but also other processes that may occur with $\mathrm{HS}^{-}$ions, for example [11]:

$$
\begin{gathered}
5 \mathrm{HS}^{-}+2 \mathrm{NO}_{3}^{-}+7 \mathrm{H}^{+} \rightarrow 5 \mathrm{~S}+\mathrm{N}_{2}+6 \mathrm{H}_{2} \mathrm{O} \\
\mathrm{HS}^{-}+4 \mathrm{NO}_{3}^{-} \rightarrow \mathrm{SO}_{4}{ }^{2-}+\mathrm{H}^{+}+4 \mathrm{NO}_{2}^{-}
\end{gathered}
$$

The process evaluated with $\mathrm{HS}^{-}$ions demonstrates both the denitrification of nitrates in the acidic environment and the formation of nitrites, sulfur, sulphate and the increase of the acidity of the environment, which confirms the different influence of sulfides on the nitrification process in water.

Because sulfides $\left(\mathrm{S}^{2-}, \mathrm{H}_{2} \mathrm{~S}\right)$ are not included in the list of monitored substances in the Regulation on environmental quality requirements for surface waters [8], but, as demonstrated in this paper, have a significant impact on biochemical processes in surface waters and, of course, they must be included in the list of parameters for monitoring and classifying the surface natural water quality.

\section{CONCLUSIONS}

The evaluation of ammonium ions nitrification process in water from Dniester River, Palanca village, Ştefan Vodă district, Republic of Moldova, shows an insignificant influence of ethyl and methyl alcohol at a concentration of $0,5 \mathrm{ml} / \mathrm{L}$.

The sulfide ion in both steps of the nitrification process has an obvious impact: in 18 days in the $\mathrm{NO}_{2}^{-} \rightarrow \mathrm{NO}_{3}^{-}$stage, only $15-35 \%$ of $\mathrm{NO}_{2}^{-}$was oxidized, compared to the comparison sample.

As a result of the modeling process the $\mathrm{pH}$ of the water decreased from 8,03 to 7,55 .

The nitrate concentration increased from $4,6 \mathrm{mg} / \mathrm{L}$ to about $13 \mathrm{mg} / \mathrm{L}$ in the comparison sample (control), but in the other samples decreasing to about $2,7 \mathrm{mg} / \mathrm{L}$ $\mathrm{NO}_{3}{ }^{-}$in water with the addition of $0,5 \mathrm{ml} / \mathrm{L} \mathrm{C}_{2} \mathrm{H}_{5} \mathrm{OH}$ and $\mathrm{CH}_{3} \mathrm{OH}$, the argument may be the denitrification of nitrates in the presence of alcohol. 
In the samples with the addition of $0,1 \mathrm{mg} / \mathrm{L} \mathrm{S}^{2-}$, including alcohols, the nitrate content did not change substantially and was $3,6-4,1 \mathrm{mg} / \mathrm{L}$, which demonstrates the impact of sulfides on the nitrification process as well as denitrification.

\section{References:}

1. Anuarul statistic al Republicii Moldova. Chişinău: Biroul Naţional de Statistică al Republicii Moldova, 2017, 486 p. ISBN 978-9975-53-418-5.

2. Al-Omari, A., Eahman, A., Okogi, S., Riffat, R., Murthy, S. Caracterizing Denitrification Kinetics in Lab Scale Reactors for Longer Time Ethanol Dosage. Journal of Water and Environment Technology, 2016, vol. 14, nr. 45, pp. 372-385. doi.10-2965/jwet.16-013.

3. Belingher M.-L., Chimerel, M.-E. Sursele de azot şi bazele procesului de nitrificaredenitrificare. Analele Universităţii "Constantin Brâncuşi”" din Târgu Jiu, Seria Inginerie, nr. 2, 2011, pp. 196-203. ISSN 1842-4856.

4. Council Directive 78/659/EEC of 18 July 1978 on the quality of fresh waters needing protection or improvement in order to support fish life.

5. Dumitru, M., Simota, C., Cioroianu, T. Codul bunelor practici agricole pentru protecţia apelor împotriva poluării cu nitraţi din surse agricole. Bucureşti, eKarioka, 2015, 164 p. ISBN 978-606-94088-0-3.

6. Garrido, J., W. van Benthum, M. van Loosdrecht, and J. Heijnen. Influence of dissolved oxygen concentration on nitrite accumulation in a biofilm airlift suspension reactor. Biotechnol. Bioeng., 1997, nr. 53, pp. 168-178.DOI:10.1002/(SICI)10970290(19970120)53:2<168::AID-BIT6>3.0.CO;2-M.

7. Guidelines for drinking-water quality, 2nd ed. Vol. 2. Health criteria and other supporting information. World Health Organization, Geneva, 1996, 9 p.https://www.who.int/water_sanitation_health/waterquality/guidelines/chemicals/hydrogensulfide.pdf?ua $=1$

8. Hotărârea Guvernului nr. 890 din 12.11.2013 pentru aprobarea Regulamentului cu privire la cerinţ̧ele de calitate a mediului pentru apele de suprafaţă. MO din 22.11.2013, Nr. 262-267, art. Nr.: 1006.

9. Hotărârea Guvernului nr. 934 din 15.08 .2007 cu privire la instituirea Sistemului informaţional automatizat „Registrul de stat al apelor minerale naturale, potabile şi băuturilor nealcoolice îmbuteliate". MO nr. 131-135 din 24.08.2007, art. nr.: 970.

10. Hotărârea Guvernului nr. 950 din 25.11.2013 pentru aprobarea Regulamentului privind cerinţele de colectare, epurare şi deversare a apelor uzate în sistemul de canalizare şi/sau în emisaruri de apă pentru localităţile urbane şi rurale. MO nr. 284-289 din 06.12.2013, art. nr. 1061.

11. Jos'e Luis Campos, Jacques Dumais et al. Predicting Accumulation of Intermediate Compounds in Nitrification and Autotrophic Denitrification Processes: A Chemical Approach. BioMed Research International, Volume 2019, Article ID 2051986, 9 p. https://doi.org/10.1155/2019/2051986. 
12. Lozan, R., Tărîţă, A., Sandu. M., et al. Starea Geoecologică a apelor de suprafata şi subterane în ,azinul hidrografic al Marii Negre (în limitele Republicii Moldova). Ch., 2015, 326 p. ISBN 978-9975-9611-2-7.

13. Metcalf and Eddy. Wastewater engineering treatment and reuse. McGraw Hill, New York. 2003, 1846 p. ISBN 0-07-112250-8.

14. Poutiainen, H., Laitinen, S., Pradhan, S., P., M., Heinonen-Tanski, H. Nitrogen Reduction in Wastewater Treatment Using Different Anox-Circulation Flow Rates and Ethanol as a Carbon Source. Environ Technol. 2010, nr. 31(6), pp. 617-623. doi: $10.1080 / 09593331003592246$.

15. Programul de alimentare cu apă şi tratare a apelor uzate din municipiul Chişinău Studiu de fezabilitate. Epurarea apelor uzate - Raport final. BCI - Seureca - Ingineria Apelor. August 2012, 99 p. https://acc.md/mmedia/2017/03/14epurarea_apelor_uzate.pdf.

16. Saleh, F. M. Drinking Water Denitrification in a Packed Bed Anoxic Reactor: Effect of Carbon Source and Reactor Depth. Journal of Applied Sciences, 2010, nr. 10, pp. 558563. DOI: 10.3923/jas.2010.558.563. ISSN 1812-5654.

17. Sandu, M. Toxicity of pesticides in the presence of heavy metals on biochemical oxidation of ammonia ions. Environmentaly sound management (ESM) practices on cleaning up obsolete stockpiles of pesticides for Central European and EECCA Countries. 2005, Sofia, pp. 179-181. ISBN-10: 954-9467-11-2; ISBN-13:978-9549467-11-6.

18. Sandu. M. , Lozan, R., Ropot, V., Munteanu, V., Rusu, V. Rolul fenolului în procesele de autoepurare ale apelor de suprafaţă. Conf. "Protecţia mediului - parte a restructurării economiei româneşti”, Bucureşti, 21-23 septembrie 1995, pp. 272 - 277.

19. Sandu, M., Lupascu, T., Tarita, A., et all. Method for nitrate determination in water in the presence of nitrite. Chemistry Journal of Moldova. General, Industrial and Ecological Chemistry. Chişinău, 2014, 9(2), pp. 8-13. ISSN 1857-1727.

20. Savia Gavazza dos Santos, Maria Bernadete Amâncio Varesche, Marcelo Zaiat, and Eugenio Foresti. Comparison of Methanol, Ethanol, and Methane as Electron Donors for Denitrification. Environmental Engineering Science, 2004, vol. 21, Issue 3, pp. 6168. http://doi.org/10.1089/109287504323066950.

21. SM EN 13177:2018. Produse chimice utilizate pentru tratarea apei destinate consumului uman. Metanol.

22. SM SR EN 26777:2006. Calitatea apei. Determinarea conţinutului de nitriţi. Metoda prin spectrometrie de absorbţie moleculară.

23. SM SR ISO 10523:2011. Calitatea apei. Determinarea pH-lui.

24. SM SR ISO 7150-1:2005. Calitatea apei. Determinarea conţinutului de amoniu. Partea 1: Metoda spectrometrică manuală.

25. Spătar,u P., Sandu, M., Dragalina, G., Arapu, T., Lozan, R. Influența produselor petroliere asupra procesului de oxidare biochimică a ionilor de amoniu. Buletinul AŞM. Seria de ştiinţe biologice, chimice şi agricole. Chişinău, 2003, nr. 2(291), pp. 128-130.

26. Spătaru, P., Sandu, M., Tărîţă, A., et all. Impactul substanţelor tensioactive asupra oxidării biochimice a ionilor de amoniu în apele naturale. Buletinul Academiei de 
Ştiinţe a Moldovei, Seria Ştiinţele Vieţii. Chişinău, 2011, 2 (311), pp. 178-184. ISSN 1857-064X.

27. Tărîţă, A., Sandu, M., Moşanu, E., Cozari, T., Lozan, R. Evaluarea componenţei fizicochimice şi indicii de calitate a apelor conexe ariilor naturale protejate de stat din raionul Anenii Noi. "Instruire prin cercetare pentru o societate prosperă", conferinţă ştiinţifico-practică, 21-22 martie 2020. Vol. 1: Biologie. Chişinău: S. n., 2020, pp. 143-154. ISBN 978-9975-76-306-6.

28. Țîrde, M., Ciobanu, A., Vasiliev, T., Buzdugan, L. Reducerea consumului nociv de alcool: analiza cost-eficacităţii strategiilor de control al alcoolului în Republica Moldova. Republica Moldova. Seria de lucrări în domeniul politicelor de sănătate. Nr. 3. Organizaţia Mondială a Sănătăţii, 2011, $54 \quad \mathrm{p}$ http://www.old2.ms.gov.md/sites/default/files/costeficacitatea_strategiilor_de_control_al_alcoolului.pdf.

(C) 2020 by the authors. Licensee UAIC, Iasi, Romania. This article is an open access article distributed under the terms and conditions of the Creative Commons Attribution (CC BY-NC-ND) license (https://creativecommons.org/licenses/by-nc-nd/4.0). 